\title{
The Australian Early Origins of Hypertension Workshop: A celebration of the scientific contributions made by Emeritus Scientia Professor Eugenie R Lumbers AM and Professor Caroline McMillen
}

The concept of fetal programming was introduced by Professor David Barker in the late 1980s based on his studies of birth weight and its correlation with death from cardiovascular diseases in adult life. ${ }^{1}$ Although this hypothesis was initially met with criticism, it has grown to be well accepted since the mid-1990s. ${ }^{2}$ However, the mechanisms underlying the link between a suboptimal intrauterine environment, the early postnatal period and health in adult life have been difficult to determine. Two outstanding fetal physiologists have made significant contributions to our understanding of the mechanistic links between alterations in the intrauterine environment and health in adult life: Professors Eugenie Lumbers and Caroline McMillen. Their remarkable contributions were celebrated recently at the Australian Early Origins of Hypertension Workshop, a satellite to the International Society for Hypertension meeting in September 2012. Forty national and international experts gathered to share their work, particularly as it relates to aspects of the contributions made by Caroline and Eugenie. Some of the studies discussed at the meeting are presented in this themed issue.

Eugenie Lumbers graduated with an MBBS from University of Adelaide and was subsequently awarded a Doctorate in Medicine from that university. In 1971, she became the first female recipient of the NHRMC CJ Martin Fellowship that led her to the Nuffield Institute for Medical Research in Oxford (1972-1973). On her return to Australia and appointment as a Senior Lecturer in 1974, she established her own laboratory at the University of New South Wales (UNSW) and has been consistently funded by the Australian Research Council, the National Health and Medical Research Council, Australian Kidney Foundation and the National Heart Foundation. In 1992, Eugenie was awarded a Vice-Chancellor's Award for Teaching Excellence. In 1993, she served on the Prime Minister's Advisory Committee for Women in Science Engineering and Technology. In 1999, Eugenie became a Scientia Professor, the first female Scientia Professor at UNSW. In 2002, she was elected to the Australian Academy of Science and received the Centenary Medal of Federation. In 2002, she was elected a Fellow of the Royal Society of NSW. In 2012, she was awarded an Order of Australia.

*Address for correspondence: Janna L. Morrison, Heart Foundation South Australian Cardiovascular Network Research Fellow Head, Early Origins of Adult Health Research Group, School of Pharmacy and Medical Sciences, Sansom Institute for Health Research, University of South Australia, GPO Box 2471, Adelaide, SA 5001, Australia.

(Email Janna.Morrison@unisa.edu.au)
Professor Lumbers' research has been broad-based: she has studied both cardiovascular and fluid and electrolyte physiology in the adult, the fetus and the newborn. ${ }^{3,4}$ She has been particularly interested in the role and actions of the renin-angiotensin system (RAS), in both animal models and humans. She discovered inactive renin ${ }^{5}$ (prorenin) and, with Brian Morris, demonstrated that it was activated by proteases. ${ }^{6}$ Most of her work in some way relates to the development of the cardiovascular system and kidney, including development of neural control of the circulation ${ }^{7}$ and programming. ${ }^{8}$ Eugenie has also made contributions to fetal gene therapy. Her current interests are related to the roles of the renin-angiotensin system in human placentation and in pregnancy-associated hypertension, ${ }^{9}$ as well as programming of renal diseases. She also has interests in the role of cardiac function in preterm neonatal hypotension. ${ }^{10}$ Eugenie is also studying the repositioning of drugs that block the renin-angiotensin system as potential anticancer drugs.

Caroline McMillen graduated with a BA (Hons) and Doctor of Philosophy at Oxford University before completing her medical degree at the University of Cambridge. She moved to Australia to take up a Lectureship at Monash University, and was appointed as Chair and Head of Physiology at the University of Adelaide in 1992. She served as Dean of the Faculty of Science and as Director of the Research Centre for the Early Origins of Adult Disease at the University of Adelaide and was appointed as Pro/Deputy Vice Chancellor Research and Innovation at the University of South Australia (UniSA) in 2005. Caroline's most recent appointment in 2011 is as Vice Chancellor at the University of Newcastle (New South Wales). Her research has been supported by the Australian Research Council and National Health and Medical Research Council for over 20 years. She was ranked in the top $1 \%$ of all Web of Science authors for the last decade in the subject area of Biology and Biochemistry.

Caroline has published seminal papers on the development of neuroendocrine control of cortisol in the developing fetus, dissecting the impact of fetal growth restriction on the developmental capacity of the cells in the pituitary, which are responsible for the stimulation of cortisol synthesis and secretion. ${ }^{11}$ Caroline's early work on the effects of placental insufficiency on the sympathoadrenal system, ${ }^{12}$ and on fetal growth, draw together the key components that link intrauterine growth retardation because of placental insufficiency (the major cause of IUGR in Western nations) as a key link in the DOHAD concept. ${ }^{13}$ Carolines's group made the observation 
that leptin acted in the brain of the fetus to cause a change in fat development. ${ }^{14}$ Furthermore, she showed that all of the appetite-regulatory neuropeptides were present in the brain of the sheep before birth; she proceeded to investigate the responses of the 'fat-brain' axis to exposure to excess nutrients in late gestation in fetal and postnatal life. ${ }^{15}$ Caroline has pioneered a unique animal model in which embryos are transferred in early life from an obese ewe to a ewe of normal body weight to show that exposure to maternal obesity during a period before and for 1 week after conception alone can result in an increase in the total mass of fat, particularly visceral fat, in her offspring. ${ }^{16}$ The work of her group on the periconceptional programming of epigenetic changes in the stress axis of the offspring ${ }^{17,18}$ and her current work on the epigenetic programming of changes in the insulin signaling and growth pathways within the liver and muscle after early nutritional restraint ${ }^{19}$ are typical of Caroline's prescience in her field.

The papers presented in this themed issue reflect the main topics of research that Eugenie and Caroline have focused on, some from their collaborators, and others from their mentees. The issue begins with two reviews that outline the impact of maternal hypoxia, ${ }^{20}$ and maternal overnutrition, ${ }^{21}$ on cardiovascular health. Giussani and Davidge ${ }^{20}$ describe the impact of prenatal hypoxia on the development of the cardiovascular system, leading to an increased risk of cardiovascular diseases in adult life. Importantly, to reflect the direction in which the field is now moving, they also describe possible interventions to prevent cardiovascular diseases. Furthermore, the physiological, structural and molecular consequences of maternal overnutrition on tissues such as the heart, kidney and skeletal tissue and, consequently, risk of cardiovascular diseases are reviewed by Blackmore and Ozanne. ${ }^{21}$ Gugusheff et al. ${ }^{22}$ show that cross-fostering offspring that were exposed to a 'junk food' diet throughout gestation onto control dams during lactation can prevent increased fat intake and fat mass, but the effect is sex dependent. Probyn et al. ${ }^{23}$ show that maternal alcohol consumption during pregnancy decreased surfactant protein B and increased fibrosis in the lung in adulthood. While Boyce et al. ${ }^{24}$ show that vitamin D supplementation during pregnancy and weaning results in an increase in renin mRNA expression in the kidney of offspring as adults.

The periconceptional period has also been identified as an important time period where maternal health can influence the health of her offspring. Lie et $a l^{25}$ show that periconceptional undernutrition in sheep alters the expression of molecules involved in cardiac growth and metabolism, with differential effects in singletons and twins. Furthermore, in the same model of periconceptional undernutiriton, Zhang et $a l^{26}$ show that both periconceptional undernutrition and undernutrition in only the first week of pregnancy reduce glucocorticoid receptor mRNA expression in the pituitary gland, which may program an increased stress response in the offspring.
Fetal growth restriction was the first known cause of fetal programming of cardiovascular health. Macko $e^{2} a l^{27}$ use the maternal hyperthermia model of fetal growth restriction to show that before growth restriction, there is an increase in fetal plasma noradrenaline that suppresses insulin secretion from the pancreas. Meyer-Gesch $e t a{ }^{28}$ used a model of uterine space restriction to induce fetal hypoxemia, hypoglycemia and growth restriction, resulting in delayed development of the kidney. While Lie $e t$ al. ${ }^{29}$ use the carunclectomy model of fetal growth restriction in sheep to show that 21 days after birth, there are changes in the protein abundance of molecules involved in lipid accumulation in omental fat that may explain the increased risk of visceral adiposity in individuals that are born growthrestricted.

Together, this collection of articles covers the main themes of research that Eugenie and Caroline continue to focus on, highlighted by the contributions that they and their mentees have made to this issue. We look forward to following their continuing body of work.

Janna L. Morrison

Heart Foundation South Australian Cardiovascular Network Research Fellow Head, Early Origins of Adult Health

Research Group, School of Pharmacy and Medical Sciences, Sansom Institute for Health Research, University of South Australia, Adelaide, Australia

Eugenie Lumbers

School of Biomedical Sciences and Pharmacy, Mothers and Babies Research Centre and Hunter Institute for Medical Research, University of Newcastle, Callaghan, Australia

Susan E. Ozanne

University of Cambridge Metabolic Research Laboratories and MRC Metabolic Diseases Unit Welcome Trust-MRC Institute of Metabolic Science, Addenbrooke's Hospital, Cambridge, UK

Catherine M. Suter

ARC Future Fellow and Head, Epigenetics Laboratory, Victor Chang Cardiac Research Institute, Darlinghurst, Australia

\section{References}

1. Barker DJ, Osmond C, Golding J, Kuh D, Wadsworth ME. Growth in utero, blood pressure in childhood and adult life, and mortality from cardiovascular disease. BMJ. 1989; 298, 564-567.

2. Rich-Edwards JW, Stampfer MJ, Manson JE, et al. Birth weight and risk of cardiovascular disease in a cohort of women followed up since 1976. BMJ. 1997; 315, 396-400.

3. Gibson KJ, Boyce AC, Thomson CL, Chinchen S, Lumbers ER. Interactions between subtotal nephrectomy and salt: effects on blood pressure and renal function in pregnant and nonpregnant ewes. Am J Physiol Regul Integr Comp Physiol. 2008; 294, R1227-1233. 
4. Gibson KJ, Lumbers ER. The effects of continuous drainage of fetal fluids on salt and water balance in fetal sheep. J Physiol. 1996; 494( Pt 2), 443-450.

5. Lumbers ER. Activation of renin in human amniotic fluid by low pH. Enzymologia. 1971; 40, 329-336.

6. Morris BJ, Lumbers ER. The activation of renin in human amniotic fluid by proteolytic enzymes. Biochim Biophys Acta. 1972; 289, 385-391.

7. Nail BS, Lumbers ER, Stevens AD. The effect of fetal lung inflation on fetal heart rate. Am J Physiol. 1994; 266(Pt 2), H1395-H1400.

8. Brandon AE, Boyce AC, Lumbers ER, Gibson KJ. Maternal renal dysfunction in sheep is associated with salt insensitivity in female offspring. J Physiol. 2009; 587(Pt 1), 261-270.

9. Zhou A, Dekker GA, Lumbers ER, et al. The association of maternal ACE A11860G with small for gestational age babies is modulated by the environment and by fetal sex: a multicentre prospective case-control study. Mol Hum Reprod. 9 May 2013 [Epub ahead of print].

10. Kandasamy Y, Smith R, Wright IM, Lumbers ER. Extra-uterine renal growth in preterm infants: oligonephropathy and prematurity. Pediatr Nephrol. 2013; 28, 1791-1796.

11. Butler TG, Schwartz J, McMillen IC. Differential effects of the early and late intrauterine environment on corticotrophic cell development. J Clin Invest. 2002; 110, 783-791.

12. Simonetta G, Rourke AK, Owens JA, Robinson JS, McMillen IC. Impact of placental restriction on the development of the sympathoadrenal system. Pediatr Res. 1997; 42, 805-811.

13. McMillen IC, Robinson JS. Developmental origins of the metabolic syndrome: prediction, plasticity, and programming. Physiol Rev. 2005; 85, 571-633.

14. Yuen BS, Owens PC, Muhlhausler BS, et al. Leptin alters the structural and functional characteristics of adipose tissue before birth. Faseb J. 2003; 17, 1102-1104.

15. Muhlhausler BS, Adam CL, Findlay PA, Duffield JA, McMillen IC. Increased maternal nutrition alters development of the appetite-regulating network in the brain. Faseb J. 2006; 20, 1257-1259.

16. Rattanatray L, MacLaughlin SM, Kleemann DO, et al. Impact of maternal periconceptional overnutrition on fat mass and expression of adipogenic and lipogenic genes in visceral and subcutaneous fat depots in the postnatal lamb. Endocrinology. 2010; 151, 5195-5205.

17. Zhang S, Rattanatray L, MacLaughlin SM, et al. Periconceptional undernutrition in normal and overweight ewes leads to increased adrenal growth and epigenetic changes in adrenal IGF2/H19 gene in offspring. The FASEB J. 2010; 24, 2772-2782.

18. Edwards LJ, McMillen IC. Impact of maternal undernutrition during the periconceptional period, fetal number, and fetal sex on the development of the hypothalamo-pituitary adrenal axis in sheep during late gestation. Biology of Reproduction. 2002; 66, 1562-1569.

19. Nicholas LM, Rattanatray L, Maclaughlin SM, et al. Differential effects of maternal obesity and weight loss in the periconceptional period on the epigenetic regulation of hepatic insulin-signaling pathways in the offspring. FASEB J. 31 May 2013 [Epub ahead of print].

20. Giussani DA, Davidge ST. Developmental programming of cardiovascular disease by prenatal hypoxia. J Dev Orig Health Dis. 2013; 4, 328-337.

21. Blackmore HL, Ozanne SE. Maternal diet-induced obesity and offspring cardiovascular health. J Dev Orig Health Dis. 2013; 4, 338-347.

22. Gugusheff JR, Vithayathil M, Ong ZY, Muhlhausler BS. The effects of prenatal exposure to a 'junk food' diet on offspring food preferences and fat deposition can be mitigated by improved nutrition during lactation. J Dev Orig Health Dis. 2013; 4, 348-357.

23. Probyn ME, Cuffe JSM, Zanini S, Moritz KM. The effects of low-moderate dose prenatal ethanol exposure on the fetal and postnatal rat lung. J Dev Orig Health Dis.. 2013; 4, 358-367.

24. Boyce AC, Palmer-Aronsten BJ, Kim MY, Gibson KJ. Maternal vitamin $\mathrm{D}$ deficiency programmes adult renal renin gene expression and renal function. J Dev Orig Health Dis. 2013; 4, 368-376.

25. Lie S, Sim SM, McMillen IC, et al. Maternal undernutrition around the time of conception and embryo number each impact on the abundance of key regulators of cardiac growth and metabolism in the fetal sheep heart. J Dev Orig Health Dis. 2013; 4, 377-390.

26. Zhang S, Williams-Wyss O, MacLaughlin SM, et al. Maternal undernutrition during the first week after conception results in decreased expression of glucocorticoid receptor mRNA in the absence of $G R$ exon $1_{7}$ hypermethylation in the fetal pituitary in late gestation. J Dev Orig Health Dis. 2013; 4, 391-401.

27. Macko AR, Yates DT, Chen X, et al. Elevated plasma norepinephrine inhibits insulin secretion, but adrenergic blockade reveals enhanced $\beta$-cell responsiveness in an ovine model of placental insufficiency at 0.7 of gestation. J Dev Orig Health Dis. 2013; 4, 402-410.

28. Meyer-Gesch KM, Sun MY, Koch JM, et al. Ovine fetal renal development impacted by multiple fetuses and uterine space restriction. J Dev Orig Health Dis. 2013; 4, 411-420.

29. Lie S, Duffield JA, McMillen IC, et al. The effect of placental restriction on insulin signaling and lipogenic pathways in omental adipose tissue in the postnatal lamb. J Dev Orig Health Dis. 2013; 4, 421-429. 